\title{
The geochemistry of the Rhine and the Rhone. 5, Synthesis and conclusions
}

\author{
H.L. Golterman ${ }^{1}$
}

Kevwords : Rivers, geochemistry, acidification, mineral composition.

Every month 2 samples of the Rhine and 1 sample of the Rhone are analysed for about 20 chemical and physical variables at 7 stations by two monitoring agencies.

This paper presents some of our conclusions on the accuracy of these programmes and on the solubility of the calcium/carbonate/sulphate/phosphate system. In total we have analysed 916 data sets; they were screened for imprecision before being used.

At all stations the water is saturated with $\mathrm{CaCO}_{3}$, but the * apparent * solubility product depends on the pH. The regression line can be described by $\mathrm{IP}_{\mathrm{ca}}=8.73 \times 10^{-15}$. $\mathrm{pH}^{15.667}$.

In both the Rhine and the Rhone an acidification is seen and an increase of the sulphate concentration when going downstream. We have shown that the increase in sulphate concentration is due to the disposal of $\mathrm{CaSO}_{4}$. This addition of sulphate influences the quotient $\mathrm{Ca} / \mathrm{HCO}_{3}$. The data fit very well the theoretical regression line $\mathrm{Ca} / \mathrm{HCO}_{3}=0.5\left(\mathrm{SO}_{4}\right)+0.5$.

The acidification originates from the mineralization of organic matter. For 6 stations dowstream from the great lakes we found that the two rivers are saturated with hydroxy-apatite, the - $\log$ of the ionic product being 49.9 (Rhine ; $\sigma=0.6$; $\mathrm{N}=259$ ) and 50.0 (Rhone ; $\sigma=0.3 ; \mathrm{N}=479$ ). The o-phosphate concentration does not therefore depend on the phosphate loading of the rivers, but on the Ca concentration, the temperature and the $\mathrm{pH}$. This has great influence on the transport of phosphate through the delta's of the two rivers. The disturbance of acidity and buffering capacity influences heavy metal behaviour as well.

Geochimie du Rhin et du Rhóne. 5, Synthèse et conclusions

Mots clés : Fleuves, géochimie, acidification, équilibre minéral.

Ine vingtaine de variables physiques et chimiques sont mesurées chaque mois par deux organismes de surveillance sur des échantillons d'eau prélevés dans 7 stations sur le Rhin et le Rhône.

Cet article présente quelques conclusions sur le degré de précision de ce programme de mesures et sur la solubilité du système Calcium/Carbonate/Sulfate/Phosphate. Un total de 916 séries de données a été analysé dont nous avons, au préalable, testé le niveau de précision.

Dans toutes les stations, l'eau est saturée en $\mathrm{CaCo}_{3}$ mais le produit de solubilité " apparent " dépend dus pH. La droite de régression s'écrit: $\mathrm{IP}_{\mathrm{Ca}}=8,73 \times 10^{-5} \cdot \mathrm{pH}^{15,667}$.

Ine acidification et une augmentation de la concentration en sulfates apparait de l'amont vers l'aval a la fois dans le Rhin et dans le Rhône. Nous avons montré que l'augmentation des concentrations de sulfates est due à la destruction du $\mathrm{CaSO}_{4}$ et qu'elle agit sur le rapport $\mathrm{Ca} / \mathrm{HCO}_{3}$. Les données s'ajustent bien à la droite de régression théorique $\mathrm{Ca} / \mathrm{HCO}_{3}$ $=0.5\left(\mathrm{SO}_{4}\right)+0,5$.

J.'acidification provient de la minéralisation de la matière organique. Dans les deux rivières, les six stations à l'aval des grands lacs sont saturées en hydroxy-apatite, le $\log$ du produit ionique étant de 49,9 (Rhin; $\sigma=0.6 ; N=259$ ) et 50 (Rhône ; $\sigma=0,3 ; N=479$ ). Par suite, la concentration en 0 . phosphate ne dépend pas de la charge de ces rivières mais des concentrations en $\mathrm{Ca}$, de la temperature et du $\mathrm{pH}$.

reci a une forte influence sur le transport de phosphates vers les deltas. La modification de l'acidité et du pouvoir tampon agit également sur le comportement des métaux lourds.

1. Station Biologique de la Tour du Valat, le Sambuc. 13200 ARLES. 


\section{Introduction}

The chemical composition of the river Rhine is monitored by fortnightly samples from seven sta. tions and that of the river Rhone by monthly sam. ples from seven stations ; for the Rhine full ionic balances are measured eight times a year. About 25 chemical and physical variables are measured and the results are published in the Commission Internationale pour la Protection du Rhin contre la Pollution and, for the Rhone, in the Annuaire de la Qualité des Eaux.

Quantitative conclusions are rarely drawn from the published data except general statements about increasing or decreasing pollution. Interactions between different variables are almost never studied.

In four articles we analysed some of these published data in more detail i.e. the data for flow rate; $\mathrm{pH}$; concentrations of $\mathrm{Ca}, \mathrm{Mg}, \mathrm{K}, \mathrm{Na}, \mathrm{Cl}, \mathrm{SO}_{4}$, $\mathrm{HCO}_{3}, \mathrm{o}-\mathrm{PO}_{4}$, Tot- $\mathrm{P}, \mathrm{O}_{2}$ : temperature and electrical conductivity.

In this article $I$ combine the conclusions of these four articles, compare them with the literature and describe possible consequences for water chemistry and management in the two deltas.

\section{1. - Methods}

Data on 15 physical and chemical variables in the Rh ine were obtained from the Commission Internationale pour la Protection du Rhin contre la Pollution (1971-1979) and in the Rhone from l'Annuaire de la Qualité des Eaux (1975-1981). They are stored in our data bank RRque. On each river 7 stations were chosen, one above the Lake of Constance (Rhine) and one above the Lake of Geneva (Rhone), and 6 at increasing distances from these lakes towards the river mouths.

When regressions are calculated between two variables two procedures can be followed. Firstly all data for each river are grouped per year, and variations with time are studied. Secondly all data for a particular station are grouped and the variations between stations are studied. The first value (" river means ") is useful for comparison with other (whole) river data, the second ("station means") may provide more information on the processes occurring, especially if conditions per station differ.
I use the following abbreviations: $\mathrm{IP}_{\mathrm{ca}}$ for the ionic product of $\mathrm{CaCO}_{3}$ and $\mathrm{IP}_{\mathrm{ap}}$ for that of hydroxy. apatite, i.e. $\left[\mathrm{Ca}^{2+}\right]^{5}\left[\mathrm{PO}_{4}{ }^{3-}\right]^{3}[\mathrm{OH}]$.

\section{2. - Hydrology}

Both rivers have their origins on The Dammastock (Switzerland, at $3630 \mathrm{~m}$ ). The Rhone originates from the Rhone glacier, the Rhine starts as a confluence of small rivulets. They descend steeply and enter respectively the Lake of Geneva (Rhone) at $380 \mathrm{~m}$ and the Lake of Constance (Rhine) at $400 \mathrm{~m}$; their flow rates are then 190 and $250 \mathrm{~m}^{3} \mathrm{sec}^{-1}$ respectively (see table 1). On leaving the lakes the rate is increased to 380 and $340 \mathrm{~m}^{3} \mathrm{sec}^{-1}$. The rivers rapidly lose more height (see figure 1) without much further increase in flow rate. The largest increases occur below $200 \mathrm{~m}$ for the Rhone and below $300 \mathrm{~m}$ for the Rhine. Flow rate at the river mouth is 1750 and $1400 \mathrm{~m}^{3} \mathrm{sec}^{-1}$ respectively.

\section{3. - Results}

In total we have used 916 data sets.

We have no absolute way of detecting the precision numerically. In the first place we have calculated the proportional imbalance (\%) if the ionic balance was complete (in a few cases we ignored missing values for sulphate and nitrate):

Proportional imbalance $=$

sum cations - sum anions $\times 100$

(sum cations + sum anions) $/ 2$

We have shown on statistical arguments that data sets should be rejected if the imbalance is $>4 \%$ for the Rhine and $>6 \%$ for the Rhone. We also used a second screening procedure, which removed those data sets in which the $I P_{c a}$ and the $I P_{\text {ap }}$ are larger or smaller than the mean values plus or minus $3 \sigma$. In only 20 data sets, out of 916 , did we find suspiciously high values for both $\mathbf{I P}_{\mathrm{ca}}$ and $\mathbf{I P}_{\mathrm{ap}}$. We have thus concluded, that there is no reason to believe that calcium values are wrong even though the ionic imbalance was high. As high and low values occurred in about equal frequency this screening yielded no difference with the calculations made with the unscreened data.

In the article I apply a further test of the reliability of the data by calculating conductivity from the 
Table 1. Water flow rate $\left(\mathrm{m}^{3} \mathrm{sec}^{-1)}\right.$ at 7 stations in the Rhine (1971-1979) and at 7 stations in the Rhone (1975-1981).

\begin{tabular}{lcclcc}
\hline & mean & range & & mean & range \\
\hline Schmitter & 250 & $(240-260)$ & Port-du-Scex & 190 & $(130-220)$ \\
Stein am Rhein & 340 & $(250-390)$ & Collonges & 380 & $(270-500)$ \\
Kembs & 1000 & $(750-1150)$ & Bourget & 450 & $(300-530)$ \\
Seltz & 1150 & $(850-1300)$ & Villeurbanne & 670 & $(480-780)$ \\
Koblenz/Br & 1500 & $(850-1350)$ & Chasse & 1100 & $(750-1400)$ \\
Bimmen/Lo & 1900 & $(1300-2500)$ & St Vallier & 1100 & $(800-1400)$ \\
Gorinchem & 1400 & $(1000-1800)$ & Tarascon & 1750 & $(1400-2300)$ \\
\hline
\end{tabular}

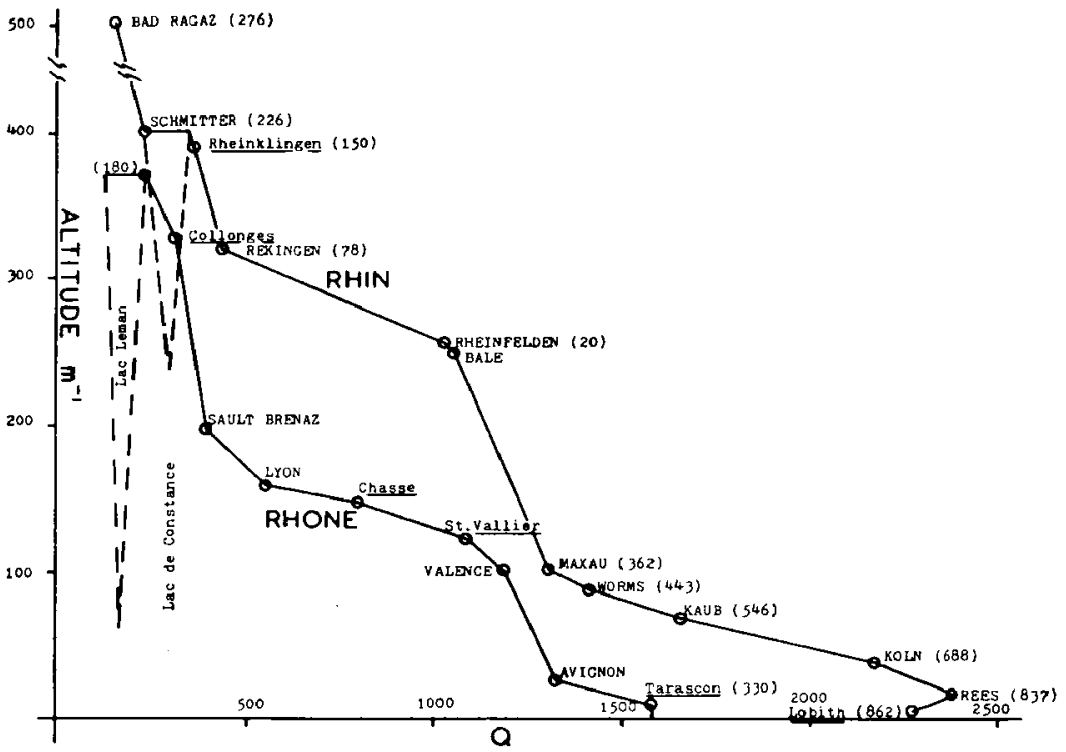

Fip. 1. Relation between flow rate $\left(\mathrm{m}^{3} \mathrm{sec}^{-1}\right)$ and altitude above sea level for the Rhine and the Rhone. Distances $(\mathrm{km})$ from Basel (Rhine) or Lyon (Rhone) in parentheses. 
Table 2. - Total number of cases for each of the stations in the Rhine and the Rhone for which conductivity data and ionic balances are available. The number of cases where the calculated conductivity is larger or smaller than $7 \%$ or $8 \%$ of the measured conductivity is given, while finally also is indicated whether the imbalance in the ionic composition is larger or smaller than $6 \%$ or $7 \%$.

The mean errors in the ionic balance are indicated between parentheses.

\begin{tabular}{|c|c|c|c|c|c|c|c|c|c|c|c|c|c|}
\hline $\begin{array}{l}\text { COND ; cale/meas. } \\
\bar{\sigma} \text { (ION, BAL.) }\end{array}$ & $\begin{array}{l}0 K \\
66\end{array}$ & $\begin{array}{l}\mathrm{OK} \\
>6\end{array}$ & $\begin{array}{l}1.07 \\
>6\end{array}$ & $<6$ & $\begin{array}{l}<0,03 \\
>6\end{array}$ & 16 & TOT & $\begin{array}{l}\text { OK } \\
67\end{array}$ & $\begin{array}{l}0 K \\
17\end{array}$ & $\begin{array}{l}1,08 \\
37\end{array}$ & 67 & $\begin{array}{l}10.92 \\
17\end{array}$ & 47 \\
\hline SCHMITTER & 32 & $\begin{array}{c}1 \\
(7)\end{array}$ & $\begin{array}{l}0 \\
-\end{array}$ & $\begin{array}{l}0 \\
-\end{array}$ & $\begin{array}{l}0 \\
-\end{array}$ & $\begin{array}{c}3 \\
|3 / 2|\end{array}$ & 36 & 34 & $\begin{array}{l}0 \\
-\end{array}$ & $\begin{array}{l}0 \\
-\end{array}$ & $\begin{array}{l}0 \\
-\end{array}$ & $\begin{array}{l}0 \\
-\end{array}$ & ${ }_{(\Delta / 2)}^{2}$ \\
\hline Stein & 21 & $\begin{array}{l}12 \\
\text { (21) }\end{array}$ & $\begin{array}{c}3 \\
(26)\end{array}$ & $\begin{array}{c}4 \\
(1)\end{array}$ & $\begin{array}{l}10 \\
(23)\end{array}$ & $\begin{array}{c}4 \\
\text { (5) }\end{array}$ & 54 & 24 & $\frac{12}{(22)}$ & $\stackrel{3}{(26)}$ & $\begin{array}{c}4 \\
(1)\end{array}$ & $\underset{(24)}{9}$ & $\underset{(2)}{2}$ \\
\hline KEMBS & 21 & $\begin{array}{l}10 \\
\text { (17) }\end{array}$ & $\begin{array}{c}2 \\
(10)\end{array}$ & $\begin{array}{c}4 \\
(2 / 2)\end{array}$ & $\begin{array}{l}11 \\
(21)\end{array}$ & $\begin{array}{c}6 \\
(3)\end{array}$ & 54 & 26 & $\begin{array}{l}10 \\
(18)\end{array}$ & $\underset{(11)}{2}$ & $\begin{array}{c}4 \\
(2)\end{array}$ & $\underset{(24)}{9}$ & $\begin{array}{r}3 \\
(4)\end{array}$ \\
\hline SELTZ & 13 & $\begin{array}{c}1 \\
\left(6 Z_{3}\right)\end{array}$ & $\begin{array}{l}0 \\
-\end{array}$ & $\begin{array}{l}15 \\
(2)\end{array}$ & $\begin{array}{l}0 \\
-\end{array}$ & $\begin{array}{l}24 \\
\text { (2) }\end{array}$ & 53 & 18 & $\begin{array}{l}0 \\
-\end{array}$ & $\begin{array}{l}0 \\
-\end{array}$ & $\begin{array}{l}14 \\
\text { (2) }\end{array}$ & 0 & $\begin{array}{c}21 \\
(2)\end{array}$ \\
\hline KOBLENZ & 17 & $\begin{array}{l}0 \\
-\end{array}$ & $\begin{array}{l}0 \\
-\end{array}$ & $\begin{array}{l}10 \\
(2)\end{array}$ & $\begin{array}{c}1 \\
\langle 19\rangle\end{array}$ & $\begin{array}{l}43 \\
(2)\end{array}$ & 71 & 23 & $\begin{array}{l}0 \\
-\end{array}$ & $\begin{array}{l}0 \\
-\end{array}$ & $\begin{array}{l}10 \\
\text { (2) }\end{array}$ & $\stackrel{1}{(19)}$ & $\begin{array}{l}37 \\
(2)\end{array}$ \\
\hline Bimmen & 30 & $\begin{array}{r}1 \\
\text { (8) }\end{array}$ & $\begin{array}{l}0 \\
-\end{array}$ & $\begin{array}{c}4 \\
\text { (3) }\end{array}$ & $\underset{(7)}{1}$ & $\begin{array}{l}36 \\
(1 \%)\end{array}$ & 72 & 35 & $\begin{array}{c}1 \\
\text { (8) }\end{array}$ & 0 & $\begin{array}{c}4 \\
\text { (3) }\end{array}$ & $\begin{array}{c}1 \\
(7)\end{array}$ & $\begin{array}{l}31 \\
(1 \mathbf{k})\end{array}$ \\
\hline GORINCHEM & 18 & $\begin{array}{r}4 \\
(9)\end{array}$ & $\begin{array}{c}3 \\
(8)\end{array}$ & $\begin{array}{c}6 \\
\text { (4) }\end{array}$ & $\begin{array}{l}15 \\
\text { (17) }\end{array}$ & $\begin{array}{l}24 \\
(2)\end{array}$ & 70 & 21 & $\begin{array}{c}7 \\
\text { (9) }\end{array}$ & $\begin{array}{c}3 \\
\{9\}\end{array}$ & $\begin{array}{c}6 \\
(4)\end{array}$ & $\begin{array}{l}10 \\
\{21\}\end{array}$ & $\begin{array}{l}23 \\
(2)\end{array}$ \\
\hline PORT-DU-SCEX & 36 & $\begin{array}{l}11 \\
(10)\end{array}$ & $\begin{array}{l}10 \\
(13)\end{array}$ & $\begin{array}{l}11 \\
\text { (2) }\end{array}$ & $\begin{array}{c}8 \\
(17)\end{array}$ & $\begin{array}{c}8 \\
\text { (3) }\end{array}$ & 84 & 43 & $\begin{array}{l}13 \\
(20)\end{array}$ & $\begin{array}{l}8 \\
\text { (14) }\end{array}$ & $\begin{array}{c}8 \\
(2)\end{array}$ & $\begin{array}{c}7 \\
\mid 19)\end{array}$ & $\begin{array}{r}5 \\
(3)\end{array}$ \\
\hline COLLONGES & 38 & $\begin{array}{r}7 \\
(7)\end{array}$ & $\begin{array}{l}0 \\
-\end{array}$ & $\begin{array}{c}1 \\
\{5\}\end{array}$ & $\begin{array}{l}10 \\
(8)\end{array}$ & $\begin{array}{l}16 \\
(3)\end{array}$ & 72 & 55 & $\begin{array}{c}6 \\
(8)\end{array}$ & $\begin{array}{l}0 \\
-\end{array}$ & $\begin{array}{l}1 \\
(4)\end{array}$ & $\begin{array}{c}3 \\
\left(9 x_{2}\right)\end{array}$ & $\stackrel{7}{(2 \xi)}$ \\
\hline BOURGET & 40 & $\begin{array}{c}7 \\
(12\})\end{array}$ & $\begin{array}{l}0 \\
-\end{array}$ & $\begin{array}{c}1 \\
(1)\end{array}$ & $\begin{array}{c}4 \\
(8)\end{array}$ & $\begin{array}{l}20 \\
(3)\end{array}$ & 72 & 55 & $\begin{array}{c}8 \\
(11)\end{array}$ & $\begin{array}{l}0 \\
-\end{array}$ & (1) & $\begin{array}{c}2 \\
(8)\end{array}$ & $\begin{array}{c}6 \\
(3)\end{array}$ \\
\hline VILL'EURBANME & 32 & $\begin{array}{l}10 \\
(9)\end{array}$ & $\begin{array}{l}0 \\
-\end{array}$ & $\begin{array}{l}0 \\
-\end{array}$ & $\begin{array}{c}5 \\
(8)\end{array}$ & $\begin{array}{l}25 \\
(2)\end{array}$ & 72 & 49 & $\begin{array}{c}5 \\
(11)\end{array}$ & $\begin{array}{l}0 \\
-\end{array}$ & $\begin{array}{l}0 . \\
-\end{array}$ & $\begin{array}{c}4 \\
\{8\}\end{array}$ & $\begin{array}{l}13 \\
\text { (2) }\end{array}$ \\
\hline ChASSE & 38 & $\begin{array}{r}1 \\
(8)\end{array}$ & $\underset{\{19\}}{1}$ & 0 & $\begin{array}{c}2 \\
(8)\end{array}$ & $\begin{array}{l}30 \\
(3)\end{array}$ & 72 & 52 & $\begin{array}{c}3 \\
\{12\}\end{array}$ & $\begin{array}{l}0 \\
-\end{array}$ & $\begin{array}{l}0 \\
-\end{array}$ & $\begin{array}{l}0 \\
-\end{array}$ & $\begin{array}{l}17 \\
(3)\end{array}$ \\
\hline St. VAlL ier & 25 & $\begin{array}{r}5 \\
(9)\end{array}$ & $\begin{array}{c}1 \\
(14)\end{array}$ & $\begin{array}{l}0 \\
-\end{array}$ & $\begin{array}{l}10 \\
\text { (8) }\end{array}$ & $\begin{array}{l}31 \\
(2)\end{array}$ & 72 & 41 & $\begin{array}{c}7 \\
(11)\end{array}$ & 0 & $\begin{array}{l}0 \\
-\end{array}$ & $\begin{array}{c}5 \\
(9)\end{array}$ & $\begin{array}{l}19 \\
(3)\end{array}$ \\
\hline TARASCON & 22 & 3 & 0 & 0 & $\begin{array}{l}15 \\
(9) \\
\end{array}$ & 30 & 70 & 28 & (5) & $\underline{0}$ & $\underline{0}$ & 90 & (38) \\
\hline & 383 & 73 & 20 & 56 & 92 & 300 & 924 & 504 & 78 & 16 & 52 & 60 & 214 \\
\hline
\end{tabular}

measured concentrations of the major ions and comparing the so-called " calculated conductivity " with the measured one. Table 2 gives the number of cases in which the calculated conductivity is more than $7 \%$ and secondly more than $8 \%$ different from the measured one. It also indicates whether the ionic imbalance is larger or smaller than $6 \%$ and secondly more than $7 \%$. The table shows that it makes little difference whether $7 \%$ \& $6 \%$ or $8 \%$ \& $7 \%$ is taken as criterion for satisfaction. With the " hard " criteria few more cases are placed in a nonsatisfactory group than with the "soft "criteria. E.o. the table shows that at Schmitter 32 cases fall in the satisfactory group if the " hard " criteria are taken and 34 if the " soft " criteria are taken. In several stations, however, fewer than half the cases fall in this group ; it makes again little difference whether " hard " of a soft " criteria are taken for satisfaction. The second largest group is the group where the ionic composition is balanced, but the calculated conductivity is too small. As the conductivity measurement is in principle relatively simple, this suggests important errors in the ionic balance, e.g. replacement of a divalent ion by another one. We have no further ways of testing these results but suggest that the methodology is carefully reexamined. 
Table 3a. - Coefficients of the regression line between ionic strength factor $[F=\sqrt{[S} /(1+\sqrt{I S})]$ and conductivity $($ Co) $\mathbf{F}=\mathbf{A}+\mathbf{B} \times \mathbf{C o}$ in 7 stations in the Rhine. Regression coefficients and standard error of the estimate are shown. The last column gives the total number of cases. For all stations except Schmitter a second line shows the results when points have been rejected because they were larger than the mean on the x-axis plus 2 times the standard devjation. In the case of Stein (and of Tarascon in Table 3b) two further subsets are shown. These are :

2) after rejecting with 2.5 times the standard deviation on the $y$-axis

3) after removing cases with error larger than $6 \%$ in the ionic balance.

\begin{tabular}{|c|c|c|c|c|c|c|}
\hline Schmitter & & 0.03 & 1.3 & .92 & 1.4 & 36 \\
\hline Stein & $\begin{array}{l}\text { 2) } \\
\text { 3) }\end{array}$ & $\begin{array}{l}0.05 \\
0.05 \\
0.05 \\
0.05\end{array}$ & $\begin{array}{l}0.46 \\
0.68 \\
0.62 \\
0.65\end{array}$ & $\begin{array}{l}.15 \\
.23 \\
.23 \\
.42\end{array}$ & $\begin{array}{l}2.9 \\
2.7 \\
2.5 \\
1.8\end{array}$ & $\begin{array}{l}54 \\
53 \\
5 \\
29\end{array}$ \\
\hline Seltz & & $\begin{array}{l}0.06 \\
0.65\end{array}$ & $\begin{array}{l}0.4 \\
0.48\end{array}$ & $\begin{array}{l}.74 \\
.72\end{array}$ & $\begin{array}{l}5.4 \\
5.4\end{array}$ & $\begin{array}{l}53 \\
52\end{array}$ \\
\hline Koblenz & & $\begin{array}{l}\text { ops } \\
\text { obs }\end{array}$ & $\begin{array}{l}0.3 \\
0.9\end{array}$ & $\begin{array}{l}.69 \\
.76\end{array}$ & $\begin{array}{l}4.6 \\
4.1\end{array}$ & $\begin{array}{l}71 \\
70\end{array}$ \\
\hline
\end{tabular}

For the calculations of the solubility products of $\mathrm{C}_{2} \mathrm{CO}_{3}$ and $\mathrm{Ca}_{5}\left(\mathrm{PO}_{4}\right)_{3} \mathrm{OH}$ the ionic activity coefficients are needed. This calculation has not of ten been done before, partly because activity coefficients in dilute solutions, which it has been assumed that fresh waters are, are near $O$, and because they cannot be calculated unless the concentration of the major ions has been measured. Golterman \& Meyer $(1985$ b) have shown that the first assumption is not true ; they found activity coefficients between 0.61 and 0.75 in the two typical hard waters of the Rhine and the Rhone. The second restriction, though very of ten true, is fortunately not true for the Rhine and the Rhone data. We have the refore tried to calculate the ionic strength "IS "from the conductivity. In the calculation of the ion activity coefficients not "IS " but the factor $\sqrt{I S} /(1+\sqrt{I S})$ is applied, so we calculated the relation between this factor and the (measured) conductivity. Table 3 gives the linear regression lines and the standard errors of the estimate. In some stations the relation is close, in others it is less so. This was partly due to the fact that of ten a single, far outlying point occurred. After rejection of these points (rejecting all points further away than $3 \sigma$ from the mean on the $x$-axis), sometimes the correlation improved much (Collonges, Bourget, Villeurbanne). In the stations Stein am Rhein and Tarascon a large variance remained; this is probably due to the variation in the chemical composition at these stations and to imprecise measurements. The regressions here did not become much better after rejecting the points further away than 2.5 times the standard deviation from the mean on the $y$-axis as well. In Stein am Rhein some improvement was found after rejecting the points with an imbalance larger than $6 \%$ in the ionic balance.

It is clear from table 3 that when the coefficient of correlation is high, the slope approaches 0.81 . 1.1 (Rhone) and 0.5 0.6 (Rhine): Schmitter shows a value nearer to the Rhone value ; the difference between the Rhine and the Rhone values reflects the higher sodium chloride concentration in the Rhine.

\section{4. - Variations in time and space}

In the stations above the lakes (Schmitter and Port-du-Scex) the calcium concent ration varies in a distinct seasonal pattern between 1.5 and $2.5 \mathrm{mmol}$ $1^{-1}$. If the $\mathrm{Ca} / \mathrm{HCO}_{3} / \mathrm{CO}_{3}$ system is in equilibrium 
Table 3b. - Idem for 7 stations of the Rhone.



with the partial $\mathrm{CO}_{2}$ pressure in the air, these changes can for the larger part be explained by the influence of the temperature on this system, with the sulphate concentration as a second influence. The temperature has an influence on the $K_{w}$, the $\mathrm{K}_{1}$. the $\mathrm{K}_{2}$ and the solubility of $\mathrm{CO}_{2}$, as in saturated solutions.

$\mathrm{Ca}=\mathrm{K}_{\mathrm{s}} \cdot\left(\mathrm{H}^{+}\right)^{2 /} / \mathrm{CO}_{2} \cdot \mathrm{K}_{1} \cdot \mathrm{K}_{2}$ :

in which $\mathrm{K}_{\mathrm{s}}=$ solubility product of $\mathrm{CaCO}_{3} ; \mathrm{K}_{1}$ and $\mathrm{K}_{2}$ the dissociation constants of $\mathrm{H}_{2} \mathrm{CO}_{3} ; \mathrm{CO}_{2}=$ concentration of carbon dioxide in equilibrium with the gas phase. $\mathrm{CO}_{2}, \mathrm{~K}_{1}$ and $\mathrm{K}_{2}$ are temperature dependent : the dependence is given in annex $I$. Table 4 gives the results of the calculations made with sulphate, $\mathrm{CO}_{2}$ pressure and temperature as independent variables. The results show that the solubility increases by $40 \%$ when the temperature decreases from $20^{\circ} \mathrm{C}$ to $0^{\circ} \mathrm{C}$, and that sulphate concentration increases the calcium solubility without changing the temperature effect.

$\mathrm{K}_{\mathrm{s}}$ is theoretically $0.45 \times 10^{-8}$ at $\mathrm{O}^{\circ} \mathrm{C}$ and 0.41 $\times 10^{-8}$ at $20^{\circ} \mathrm{C}$ (Stumm and Morgan, 1981). At Schmitter we have found $0.6 \times 10^{-8}$ (range 0.3 0.9 ) and at Port-du-Scex $0.3 \times 10^{-8}$ (range $0.2-0.6$ ), but no seasonal variation can be detected (see table I and II in Golterman \& Meyer, 1985b). High values, however, occur in April and May. The small differences in the calcium concentration are probably more related to the higher $\mathrm{pH}$ values in Schmitter compared to those in Port-du-Scex than to an essential difference in the apparent solubility product.

Sulphate concentrations show seasonal variations at these two stations clearly related to water flow (see fig. 2a). This variation is therefore probably an erosion effect 1 . Through the sulphate concentration the flow rate may influence the $\mathrm{Ca} / \mathrm{HCO}_{3} / \mathrm{CO}_{3}$ system. In the stations downstream, this natural pattern is no longer visible. Both $\mathrm{Ca}$ and $\mathrm{SO}_{4}$ concentration fluctuate at high levels and the variations seem to be related more to human impact ; the high calcium concentration depends on increased acidity (see below), the sulphate concentration on the disposal of gypsum. Sulphate still shows some relation with the water flow, but this relation is not always clear (e.g. see Tarascon \& Gorinchem, fig. 2b).

In both the Rhine and the Rhone we see an acidification and increase of sulphate concentration when going dowstream. Often these are assumed to be chemically related. However, Golterman \& Meyer (1985c) have shown that there is only a weak regression between $\mathrm{Ca} / \mathrm{HCO}_{3}$ and $\mathrm{pH}$, but a very strong

\footnotetext{
1. Rough estimates show that less than $10 \%$ (probably less than $5 \%$ ) of the sulphate in the Rhine (about 1 mmol $1^{-1 !}$ may be derived from acid rain.
} 
Table 4. - Solubilities of $\mathrm{Ca}^{2+}$ (in $\mathrm{mM} \mathrm{Ca}^{2+}$ ) at $20^{\circ} \mathrm{C}$ and at $0^{\circ} \mathrm{C}$ and their ratio $\mathrm{R}^{20} / 0$ and concomitant pH (in parentheses) as a function of the concentrations of sulphate ( $\mathrm{mM}$ ) and carbon dioxide (atm).

Third and fourth line the same, but now with $\mathrm{K}_{\mathrm{s}}$ calculted as a function of $\mathrm{pH}: \mathrm{K}_{\mathrm{s}}=8.73 \mathrm{pH}^{15.667} \times 10^{-23}$ (but with the theoretical $K_{s}$ as minimum value).

\begin{tabular}{|c|c|c|c|c|c|c|c|c|c|c|}
\hline \multirow{6}{*}{$\begin{array}{c}\text { Temp } \\
0 \mathrm{mM} \mathrm{SO} \\
1 \mathrm{mM} \mathrm{S0}_{4} \\
0 \mathrm{mM} \mathrm{S0} \mathrm{SO}_{4} \\
1 \mathrm{mM} \mathrm{S} 0_{4}\end{array}$} & \multicolumn{6}{|c|}{$\mathrm{CO}_{2}=10^{-3.5}$} & \multicolumn{4}{|c|}{$\mathrm{CO}_{2}=10^{-2}$} \\
\hline & \multicolumn{2}{|c|}{$20^{\circ} \mathrm{C}$} & \multicolumn{2}{|c|}{$0^{\circ} \mathrm{C}$} & \multirow{5}{*}{$\begin{array}{l}\mathrm{R}^{20 /} 0 \\
1.39 \\
1.39 \\
1.37 \\
1.36\end{array}$} & \multicolumn{2}{|c|}{$20^{\circ} \mathrm{C}$} & \multicolumn{2}{|c|}{$0^{\circ} \mathrm{C}$} & \multirow{5}{*}{$\begin{array}{l}\mathrm{R}^{20 \%} \mathrm{O} \\
1.39 \\
1.39 \\
1.41 \\
1.40\end{array}$} \\
\hline & 0.57 & (8.36) & 0.80 & $(8.41)$ & & 1.79 & $(7.36)$ & 2.53 & $(7.41)$ & \\
\hline & 0.91 & $(8.26)$ & 1.28 & $(8.3)$ & & 2.85 & $(7.26)$ & 4.00 & $(7.31)$ & \\
\hline & 3.60 & & 4.92 & & & 1.79 & & 2.53 & & \\
\hline & 4.73 & & 6.42 & & & 2.85 & & 4.00 & & \\
\hline
\end{tabular}

one between $\mathrm{Ca} / \mathrm{HCO}_{3}$ and sulphate. This indicates that the increase in sulphate is caused by an input of sulphate in the form of $\mathrm{CaSO}_{4}$ rather than as $\mathrm{H}_{2} \mathrm{SO}_{4}$, the acidification originating from the mineralization of organic matter.

Golterman \& Meyer (1985c) have shown that the addition of $\mathrm{CaSO}_{4}$ influences the quotient $\mathrm{Ca} / \mathrm{HCO}_{3}$ and therefore the $\mathrm{Ca} / \mathrm{HCO}_{3} / \mathrm{CO}_{3}$ system, according to the relation.

$$
\begin{aligned}
\mathrm{Ca}^{2+}+2\left(\mathrm{HCO}_{3}-\underset{\alpha \mathrm{CaCO}_{3 \downarrow}+\mathrm{SO}_{4}^{2-}}{\leftrightarrows} \mathrm{CO}_{3}^{2-}\right)+\mathrm{Ca}^{2+}+\mathrm{SO}_{4}^{2-} \rightarrow \\
\text { (II) }
\end{aligned}
$$

( $\alpha$ is the mol fraction of carbonate that will precipitate).

In a saturated situation, when doubling the $\mathrm{Ca}$ concentration, the carbonate concentration needs only to be halved in order to re-establish equili. brium, so $\alpha$ is very small compared with the molarity of the calcium bicarbonate present.

Theoretically the regression line should be $\mathrm{Ca} / \mathrm{HCO}_{3}=0.5\left(\mathrm{SO}_{4}\right)+0.5$ when the concentrations are expressed in $\mathrm{mmol} \mathrm{I}^{-1}$ and $\mathrm{Ca} / \mathrm{HCO}_{3}=0.5\left(\mathrm{SO}_{4}\right)$ +1 when the concentrations are expressed in meq. $1^{-1}$ with the bicarbonate originally present being 2 meq $\mathrm{I}^{-1}$.

If all data are taken together per river per year, the value of $r^{2}$ is high, and the slopes approach the theoretical value 0.5 , while if the data are taken together per station the values of $r^{2}$ are less high, probably because of a lower variation per station than for all stations together. For Schmit ter and Port-du Scex the $r^{2}$ values are smaller $\left(\mathrm{r}^{2}=0.31\right.$ and 0.28 respectively), while the slopes are less steep $(0.1$ and 0.3 , see Golterman \& Meyer, $1985 \mathrm{c}$ ). I therefore believe that in these stations the seasonal variations of the calcium and bicarbonate concentrations are for the larger part controlled by the temperature and the $\mathrm{CO}_{2}$ - partial pressure, with sulphate as a small modifying factor.

However, IP $\mathrm{Ca}_{\mathrm{ca}}$ and thus $\mathrm{K}_{\mathrm{s}}$ (from formula I) seems not to be a constant. When calculating the ionic product $\mathrm{IP}_{\mathrm{ca} \text {, }}$ we have found a strong relationship between the calculated $\mathrm{IP}_{\mathrm{ca}}$ and $\mathrm{pH}$, which are described by the following (numerical) regression equations :

RHONE : IP $\mathbf{c a}_{\mathrm{ca}}=2.17 \times 10^{-14} \cdot \mathrm{pH}^{15.2}$ (river mean)
$\mathrm{IP}_{\mathrm{ca}}=2.01 \times 10^{-17} \cdot \mathrm{pH}^{18.6}$ (stations mean)
RHINE : IP $\mathrm{Pa}_{\mathrm{ca}}=8.16 \times 10^{-16} \cdot \mathrm{pH}^{16.8}$ (stations mean)
$\mathrm{IP}_{\mathrm{ca}}=4.97 \times 10^{-12} \cdot \mathrm{pH}^{12.6}$ (river mean).

The overall mean equation for this set is

$I P_{\text {ca }}=8.73 \times 10^{-15} \cdot \mathrm{pH}^{15.667}$

Between pH 7.0 and 8.2 the 4 lines do not differ substantially from the overall mean (see fig. 3). I have now recalculated the influence of the temperature on the solubility of $\mathrm{CaCO}_{3}$, taking into account the influence of the $\mathrm{pH}$ on the $\mathrm{K}_{\mathrm{s}}$. The results are given in table 4 and show that, although the concentration of $\mathrm{Ca}$ is considerably higher, the ratio of $\left(\mathrm{Ca}^{2+}\right) 0^{\circ} \mathrm{C} /\left(\mathrm{Ca}^{2+}{ }_{20}^{\circ} \mathrm{C}\right.$ remains constant.

In the next article Golterman \& Meyer (1985 d) have calculated the ion ic product of hydroxy-apatite, $\mathrm{Ca}_{5}\left(\mathrm{PO}_{4}\right)_{3} \mathrm{OH}$, in order to test whether the solubility product is an applicable concept for natural water. If the concept holds true, then in a lot of cases the value of the ionic product will be close to that of the (still unknown) solubility product. In many cases where the ionic product is not close to the solubility product the explanation is undersaturation. This seems to be the case for the stations above the two lakes, i.e. Schmitter and Port-du-Scex, and they were 

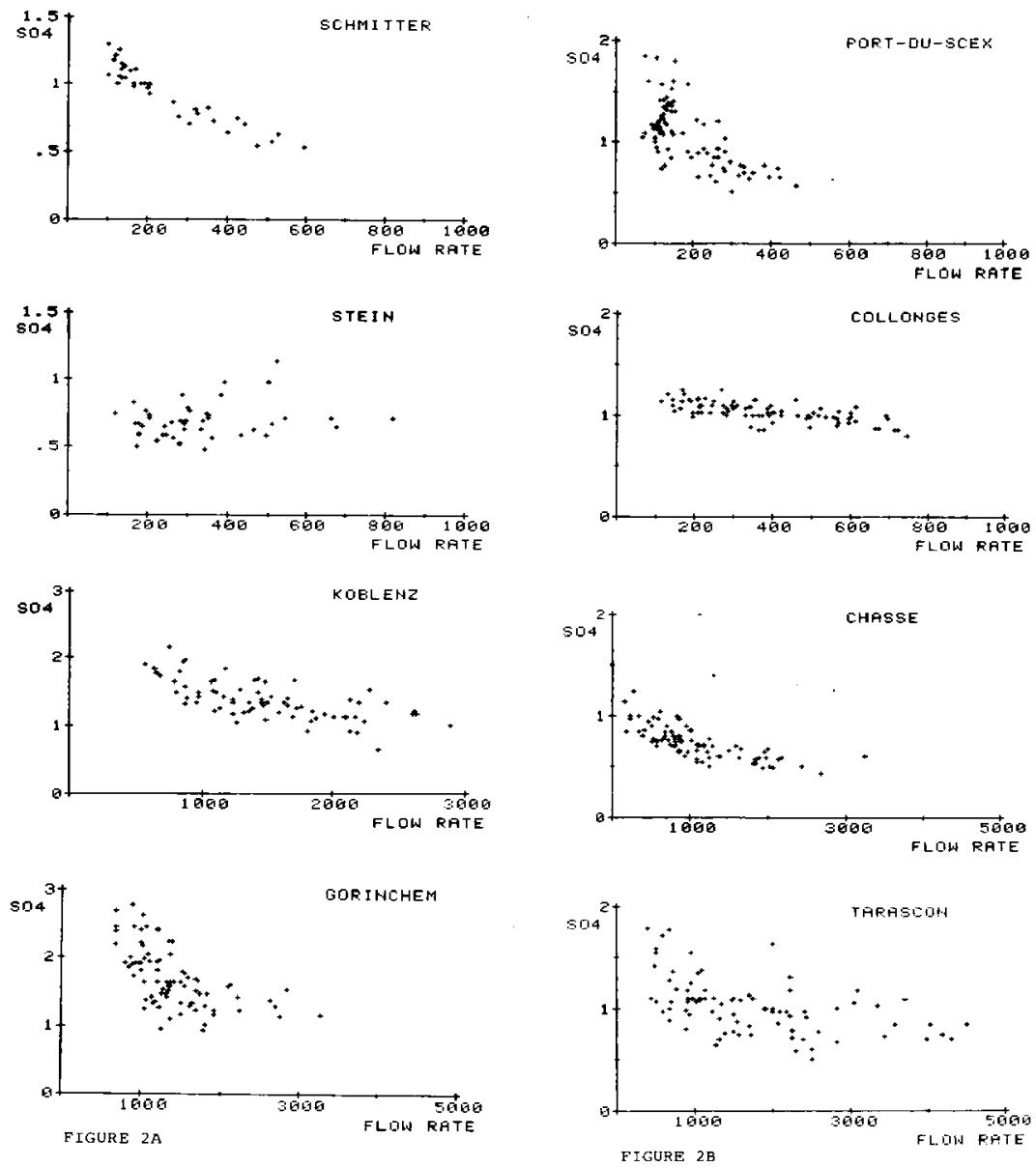

Fig. 2. Sulphate (mmol $1^{-1} ; \mathrm{y}$-axis) against flow rate $\left(\mathrm{m}^{3} \mathrm{sec}^{-1} ; \mathrm{x}\right.$-axis) in 1 station upstream and 3 stations downstream of the Lakes of Constance and Geneva.

2A. River Rhine - 2B. River Rhone. 


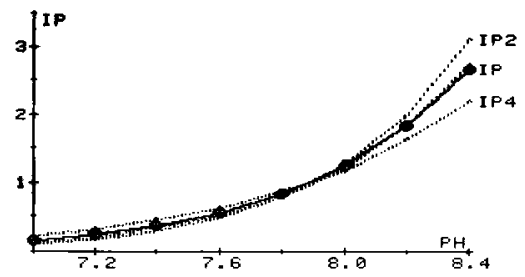

Fip. 3. 4 regression lines between $I_{\mathrm{ca}}\left(\mathrm{mol}^{2} \mathrm{1}^{-1}: \times 10^{8}\right)$ and $\mathrm{pH}$. The lines IP1 and IP3 fall together with the "mean " line.

therefore omitted. For the other stations we found a mean value for $\log \mathrm{IP}_{\text {ap }}=49.9$ (Rhine: $\sigma=0.6$; $\mathrm{N}=259$ ) and 50.0 (Rhone : $\sigma=0.3 ; \mathbf{N}=479$ ). This means that the two rivers are saturated with respect to hydroxy-apatite and that the concept holds true.

There are many measurements of $I P_{\text {ap }}$ in the literature and the data range between $10^{-50}$ and $10^{-58}$. Our analysis confirms the highest value. Most often, however, a wrong value for the $\mathrm{K}_{3}$ of $\mathrm{H}_{3} \mathrm{PO}_{4}$ has been used, without influence of the temperature on the system constants (see discussion in Golterman \& Meyer, 1985d) ${ }^{2}$. The agreement with the value presented in this article is therefore probably accidental.

Kramer (1964) used values between $10^{-55.8}\left(0^{\circ} \mathrm{C}\right)$ and $10^{-57.2}\left(30^{\circ} \mathrm{C}\right)$. Jahnke $(1981)$ reported values ranging between $10^{-54.6}$ and $10^{-58.8}$ (values are renorted on a half unit cell basis). Neither Kramer nor Jahnke indicate, however, which value for $\mathrm{K}_{3}$ was used. They pointed out, that the ionic products give no information on the composition of the solid phase due to incongruent dissolution of the hydroxyapatite. The ionic products enable us to calculate only what concentrations of o-phosphate and cal. cinm can co-exist at a given temperature and $\mathrm{pH}$. If nure hydroxy-apatite were to be brought into solution, the ratio of $\mathrm{Ca}$ : $\mathrm{P}$ would, of course, be different (although the solubility product would remain the same). As we are dealing with hard waters - often carrying still undissolved $\mathrm{CaCO}_{3}$ - to which phosphate is being added, the composition of the solid

2. In Golterman \& Meyer (1985d) a wrong formula for the third dissociation constant of $\mathrm{H}_{3} \mathrm{PO}_{4}\left(\mathrm{~K}_{3}\right)$ was printed ; the correct one $\mathrm{pK}_{3}=2397.4 /(273+\mathrm{T})+4.2364-\left(2.6061 \times 10^{-2}\right)(\mathbf{T}+273)$ $+\left(8.3834 \times 10^{-5}\right)(273+T)^{2}\left(\right.$ Temp. in $\left.{ }^{\circ} \mathrm{C}\right)$ was used. phase is mainly $\mathrm{CaCO}_{3}$ with coprecipitated apatite. The calcium concentrations in these waters are usually controlled by the solubility of the $\mathrm{CaCO}_{3}$ system and range therefore between 2 (equilibrium situation) and 4-5 mmol $1^{-1}$ (acidified waters). Thus the acidification of hard waters by decomposition of organic matter influences not only o-phosphate concentrations and its transport through delta areas, but also other processes depending on the $\mathrm{pH}$, such as speciation and transport of heavy metals.

The difference between Kramer's and Jahnke's values and ours is also due to the fact that we did not calculate the influence of the ionic activity coefficients. For the Rhine and Rhone this is possible, but the ionic composition is usually not recorded in the limnological literature, and comparison with our value would become more difficult. Because the ionic activity coefficients influence the dissociation constants as well, the influence of the activity coefficient is $\mathrm{pH}$ dependent. I estimate that for hard water rivers or lakes, at $\mathrm{pH}$ between 7 and 8 the activity coefficient is about 0.1 and the solubility product decreases to about $10^{-51}$

\section{5. - Problems and conclusions}

\section{1. - The problems}

The ionic product and the solubility product should be calculated taking into account the influence of the ion activity coefficients. However, in many studies on the solubility of phosphate in relation to calcium concentration and $\mathrm{pH}$, the concentrations of other ions are not sufficiently or not at all known. Therefore, we give the ionic product of apatite without a correction for the ion activity coefficients assuming that - as we are dealing here only with calcium rich waters - in this type of water the main components are the calcium and bicarbonate ions, and that therefore these corrections will usually be of the same magnitude. For further precise understanding in studies of the solubility of apatite, the total ionic composition should be measured.

The second problem is that in calculation of the ionic product we use the third dissociation constant of phosphoric acid, $\mathrm{K}_{3}$ (Clymo \& Golterman 1985). The value of this constant and especially its dependance on temperature, is not very well known. We know of only one series of measurements in the 
temperature range of natural waters (Ghosh el al. 1980). There are many measurements at $20^{\circ} \mathrm{C}$ and the agreement is not good. The range of values published in the literature is $2-20 \times 10^{-13}$ (Gosh el al. 1980). A fairly small change of $\mathrm{K}_{3}$ would cause a oreat difference in the $\mathrm{IP}_{\text {ap }}$ (and thus in the $\mathbf{K}_{\mathrm{s}}$ ). but not in its standard deviation. The ionic product is furthermore extremely dependent on the $\mathrm{pH}$. The observed variation around the mean value could easily be attributed to errors in the measurement of the $\mathrm{pH}$. For a more precise measurement the $\mathrm{pH}$ should be measured to an accuracy of 0.02 units (Clyrno \& Golterman 1985).

\section{2. - Conclusions}

The value for the solubility product does not give anv information on the chemical composition of the precipitate, only on which concentrations of calcium and phosphate can co-exist at a given $\mathrm{pH}$ and temperature. A solution of these ions will have a completely different composition if the solution is in eouilibrium with " pure " apatite or with a solution with a fixed calcium carbonate concentration, e.g. such as exists in natural fresh waters, where phosphate is being added to existing solutions of calcium birarbonate, the calcium concentration being controlled by the solubility of calcium carbonate at a given $\mathrm{pH}$ and temperature.

The solubility of o-phosphate and its dependence on calcium concentration and $\mathrm{pH}$ can be shown (calculated) as :

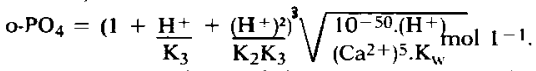

Thus, if water of one of the rivers arrives at the delta, slightly acidified (e.g. $\mathrm{pH}=7.5$ ) with $\mathrm{Ca}=$ $60 \mathrm{mg} 1^{-1}$, the o-phosphate concentration in the saturated situation will be $0.2 \mathrm{mg} l^{-1}$. Then, after re-establishing equilibrium with the air, the $\mathrm{pH}$ will increase to 8.3 , the calcium will precipitate to about $40 \mathrm{mg}^{-1}$ and the o-phosphate concentration will decrease to about $0.04 \mathrm{mg} \mathrm{1}^{-1}$. Thus $0.16 \mathrm{mg}^{-1}$ $\left(=\mathrm{g} \mathrm{m}^{3}\right)$ will precipitate. For the Rhone delta this means a precipitation of $400.10^{6} \times 0.16 \mathrm{~g} \mathrm{~m}^{3}=64$ ton $\mathrm{y}^{-1}$. Besides this amount all phosphate adsorbed on the sedimenting material will enter the bottom sediments. Finally, photosynthesis may further increase the $\mathrm{pH}$, causing a second precipitation (although this quantity is smaller than that rendered insoluble as a result of the first $\mathrm{pH}$ increase, because the remaining dissolved fraction after reequilibrating is already very small). In the Rhine delta similar processes occur on an even larger scale, both in the Haringvliet, where some $70 \%$ of the Rhine water re-equilibrates with the atmosphere and in Lake IJselmeer, through which about $10 \%$ of the Rhine water $\left(7.10^{9} \mathrm{~m}^{3} \mathrm{y}^{-1}\right)$ passes.

The second conclusion is that the o-phosphate concentration does not depend on the phosphate loading of the river, but on the calcium concentration toge. ther with temperature and $\mathrm{pH}$. Decreasing the loading may not reduce the dissolved phosphate and increasing the loading will cause only the suspended phosphate to increase. The measurement of the suspended phosphate annual transport is more difficult that that of the dissolved and the frequency of sampling should be determined by the flow rate and should not be at fixed intervals e.g. fortnightly. The consequences for monitoring programmes a re considerable.

Two remarks on the practical usefulness of the monitoring programmes must be made:

1. Since 1979 bicarbonate concentration in the Rhine is no longer being published. This means that checking the precision of the data is no longer possible. Secondly bicarbonate is a key-element in the understanding of the relationship between calcium, sulphate and phosphate concentrations. It seems highly desirable that bicarbonate be once more included in the published reports. In the Rhone the Tot-P concentration is not being measured. As the o-phosphate concentration depends on the calcium concentration. the $\mathrm{pH}$ and the temperature $A N D$ NOT ON THE LOADING, it would be useful to include the Tot-P determination in order to be able to calculate the total phosphage loading of the river. 2. In several stations a much better accuracy can be obtained. The station SCHMITTER should be compared with obtained data to see whether improvements are possible.

\footnotetext{
Annex

The temperature dependence of the $\mathrm{pK}_{1}, \mathrm{pK}_{2}$ and the solubility of $\mathrm{CO}_{2}$ is calculated as : $\mathrm{pK}_{1}=6.57886876-0.01321 \times \mathrm{TE}+1.801022 \times$ $10^{-4} \times \mathrm{TE}^{2}-6.33015138 \times 10^{-7} \times \mathrm{TE}^{3}$ $\mathrm{pK}_{2}=10.6259395-0.0147603436 \times \mathrm{TE}+$ $1.18529764 \times 10^{-4} \times \mathrm{TE}^{2}-8.08342353 \times$ $10^{-8} \times \mathrm{TE}^{3}$.

$\begin{aligned} \mathrm{CO}_{2}= & \left(130.83-0.82506 \times \mathrm{TE}+1.3116 \times 10^{-3}\right. \\ & \left.\times \mathrm{TE}^{2}\right) \times 10^{-3.5} / 44\end{aligned}$
} 


\section{References}

Annuaire de la Oualité des Eaux. Rivières et Canaux 1976 - 1981 vol, $V I$, Bassin Rhòne - Mediterranée - Corse.

Clvmo (R.S.) \% Golterman (H.L.). 1985. - Precision and accuracy of the determination of the ionic product of hydroxy-apatite. Hydrobiologia,

Commission internationale pour la protection du Rhin contre la pollution. Tableaux numériques 1971-1979.

Golterman (H.L.) \& Meyer (M.L.). 1985. - The geochemistry of two hard water rivers, the Rhine and the Rhone. Part I: Presentation and screening of dala. Hydrobiologia, 126, 3-10.

Golterman (H.L.) \& Meyer (M.L.). 1985b. - The geochernistry of two hard water rivers, the Rhine and the Rhone. Part 2 : The apparent solubility product of calcium carbonate. Hydrobiologia, 126, 11-19.
Golterman (H.L.) \& Meyer (M.L.). 1985 c. - The geochemistry of two water rivers, the Rhine and the Rhone. Part 3: The relations between calcium, bicarbonate sulphate and pH. Hydrobiologia, 126, 21.24.

Golterman (H.L.) \& Meyer (M.L.) 1985 d. - The geochemistry of two hard water rivers, the Rhine and the Rhone. Part 4: The apparent solubility product of hydroxy-apatite. Hydrobiologia, 126, 25.29 .

Ghosh (A.K.), Ghosh (J.C.) \& Prasad (B.). 1980. - Third dissociation constant of phosphoric acid from $283,15 \mathrm{~K}$ to $323,15 \mathrm{~K}$. J. Indian Chem. Soc., vol. LVI, 1194-1199.

Jahnke (R.A.), 1981. - Current phosphorite formation and the solubility of synthetic carbonate fluor apatite. Thesis University of Washington.

Kramer (J.R.). 1964. - Sea Water : Saturation with apatites and carbonates. Science : $146,637-8$

Stumm (W.) \& Morgan (J.J.). 1981. - Aquatic Chemistry. An introduction emphasizing chemical equilibria in natural waters. 780 pp. John Wiley \& Sons, Inc. New York etc. 